\title{
Cytogenetic analysis of five Hypostomus species (Siluriformes, Loricariidae)
}

\author{
Emanuel Ricardo Monteiro Martinez ${ }^{1}$, Claudio Henrique Zawadzki ${ }^{2}$, Fausto Foresti ${ }^{1}$ and Claudio Oliveira ${ }^{1}$ \\ ${ }^{1}$ Laboratório de Biologia e Genética de Peixes, Departamento de Morfologia, Instituto de Biociências, \\ Universidade Estadual Paulista "Júlio de Mesquita Filho", Botucatu, SP, Brazil. \\ ${ }^{2}$ Núcleo de Pesquisas em Limnologia, Ictiologia e Aqüicultura, Departamento de Biologia, \\ Universidade Estadual de Maringá, Maringá, PR, Brazil.
}

\begin{abstract}
In this work, we analyzed the karyotypes of five Hypostomus species. Hypostomus cf. heraldoi, from the Mogi-Guaçu River, had $2 n=72$ chromosomes, with a nucleolar organizer region (NOR) in one chromosomal pair. Hypostomus regani, from the Mogi-Guaçu River had $2 \mathrm{n}=72$ chromosomes with NORs in two chromosomal pairs. Hypostomus sp., from the Mogi-Guaçu River basin, had $2 n=68$ chromosomes, with NORs in two chromosomal pairs. Hypostomus aff. agna, from Cavalo Stream, had $2 n=74$ chromosomes with NORs in two chromosomal pairs. Hypostomus cf. topavae, from Carrapato Stream, had $2 n=80$ chromosomes, with NORs in two chromosomal pairs. Hypostomus species showed marked diversity in the karyotypic formula, which suggested the occurrence of several Robertsonian rearrangements and pericentric inversions during the evolutionary history of this genus. This hypothesis was supported by the occurrence of a large number of uniarmed chromosomes and multiple NORs in a terminal position in most species and may be a derived condition in the Loricariidae.
\end{abstract}

Key words: chromosomes, evolution, Hypostominae, Neotropical fish, NOR.

Received: February 1, 2011; Accepted: June 15, 2011.

\section{Introduction}

Siluriformes is an extremely large fish order with a wide distribution throughout tropical regions (Ferraris, 2007). The number of known species in this region is about 3,100, but may be considerably higher (Reis et al., 2003; Nelson, 2006; Ferraris, 2007). The largest family within the Siluriformes is the Loricariidae, with approximately 700 species distributed in eight subfamilies (Reis et al., 2006; Ferraris, 2007; Chiachio et al., 2008).

Loricariids occur in several habitats, from lagoons and swamps to rapids in sloping streams or rivers with rocky bottoms, at altitudes up to $3000 \mathrm{~m}$. In large water channels, these fish are usually found on rocky bottoms facing into strong water currents (Garavello and Garavello, 2004) or along the margins where the current is moderate (Burgess, 1989). According to Suzuki et al. (2000), these fish exhibit a large diversity of adaptive strategies, with many species showing nest defense, parental care of eggs, brooder larvae behavior, and mouths adapted for feeding on algae and detritus.

Although the Loricariidae is one of the largest fish families in the world, the number of cytogenetically studied

Send correspondence to Emanuel Ricardo Monteiro Martinez. Laboratório de Biologia e Genética de Peixes, Departamento de Morfologia, Instituto de Biociências, Universidade Estadual Paulista "Júlio de Mesquita Filho", 18618-970 Botucatu, SP, Brazil. E-mail: erm_martinez@yahoo.com.br. species is still very low. There is marked inter-specific diversification in the diploid number, which ranges from $2 \mathrm{n}=36$ chromosomes in Rineloricaria latirostris (Giuliano-Caetano L, Doctoral thesis, Universidade Federal de São Carlos, 1998) to $2 \mathrm{n}=84$ in Hypostomus sp. (Cereali et al., 2008). Cytogenetically, the Hypostominae is the best studied group within the Loricariidae, but it is also the most complex, with the diploid number varying from $2 n=38$ in Ancistrus sp. (Alves et al., 2003) to $2 \mathrm{n}=84$ in Hypostomus sp. (Cereali et al., 2008). A very interesting feature in the Hypostominae (particularly within Hypostomini) is the inverse relationship between the diploid number and the number of chromosomes with two arms, which suggests the occurrence of several events of centric fusion/fission (Robertsonian rearrangements) during the evolution of this group (Artoni and Bertollo, 2001).

The Hypostomini consists of a single genus, Hypostomus, whose representatives have a relatively small, stout body, without a depressed caudal peduncle and adipose fin (Armbruster, 2004). This genus, which contains 125 valid species (Zawadzki et al., 2008a; Carvalho et al., 2010) and is distributed from Central America to southern South America (Ferraris, 2007), has the greatest karyotypic diversity within the family (Artoni and Bertollo, 1996, 2001; Artoni et al., 1998). According to Artoni and Bertollo (1996), these fish exhibit non-conservative characteristics in diploid number, karyotypic macrostructure and chromo- 
somal banding (Artoni and Bertollo, 1996). Currently, most of the cytogenetic data on Hypostomus relate to the diploid number, karyotypic formulas and location of the NOR (Rubert et al., 2008). The diploid number ranges from $2 \mathrm{n}=52$ in Hypostomus emarginatus (Artoni and Bertollo, 2001) to $2 \mathrm{n}=84$ in Hypostomus sp. (Cereali et al., 2008) (Table 2). Some species have distinct karyotypic formulas and their chromosomal variation is accompanied by an increase in the number of subtelo/acrocentric chromosomes (Table 2). According to Artoni and Bertollo (1996), chromosomal rearrangements, such as centric fission and pericentric inversions, play an important role in the karyotype evolution of these fish. Sex chromosomes have been found in some Hypostominae, such as Hypostomus sp., with ZZ/ZW (Artoni et al., 1998) and Ancistrus sp. 1, with $\mathrm{XX} / \mathrm{X} 0$ (Alves et al., 2006). Hypostomus has single or multiple NORs in the terminal portion of the chromosomes, as observed for other species of this genus (Table 2), with the number of silver-stained chromosomes varying from one (Artoni and Bertollo, 1996; Cereali et al., 2008) to three (Artoni and Bertollo, 1996; Alves et al., 2006) pairs.

Several Hypostomus species are morphologically very similar (Schubart, 1964; Schaefer, 1987; Reis et al., 1990; Muller and Weber, 1992; Mazzoni et al., 1994; Weber and Montoya-Burgos, 2002; Oyakawa et al., 2005; Zawadzki et al., 2008a,c), which makes their identification difficult. In addition, several new species await formal description. Cytogenetic studies have been very useful taxonomically since several fish groups identified only on the basis of morphological studies have been further characterized as a cluster of two or more isolated genetic units.
To improve our knowledge of the diversity and species relationships in Hypostomus, in this study we undertook a cytogenetic analysis of five species in this genus. We provide information on the karyotypic organization of these species and discuss some aspects of karyotypic evolution in this group of fish.

\section{Material and Methods}

Specimens of five species of Hypostomus were collected in streams and rivers from the upper Paraná River basin and Atlantic coastal Rivers (Figure 1, Table 1). The specimens were collected under a license from Instituto Brasileiro do Meio Ambiente e dos Recursos Naturais Renováveis (IBAMA). After the cytogenetic procedures, the fish were fixed in $10 \%$ formaldehyde and preserved in $70 \%$ ethanol for future taxonomic studies. Voucher specimens were deposited in the ichthyological collection of the Laboratório de Biologia e Genética de Peixes (LBP) of the Departamento de Morfologia do Instituto de Biociências, Universidade Estadual Paulista "Júlio de Mesquita Filho", campus of Botucatu, São Paulo state.

Chromosomal preparations were obtained using the air drying technique (Foresti et al., 1981) and nucleolar organizer regions (NORs) were detected by the silver impregnation technique of Howell and Black (1980). Chromosomal morphology was established based on the proportions of the arms, as proposed by Levan et al. (1964), and the chromosomal nomenclature commonly applied to fish (a - acrocentric, $\mathrm{m}$ - metacentric, sm - submetacentric and st - subtelocentric) was used.

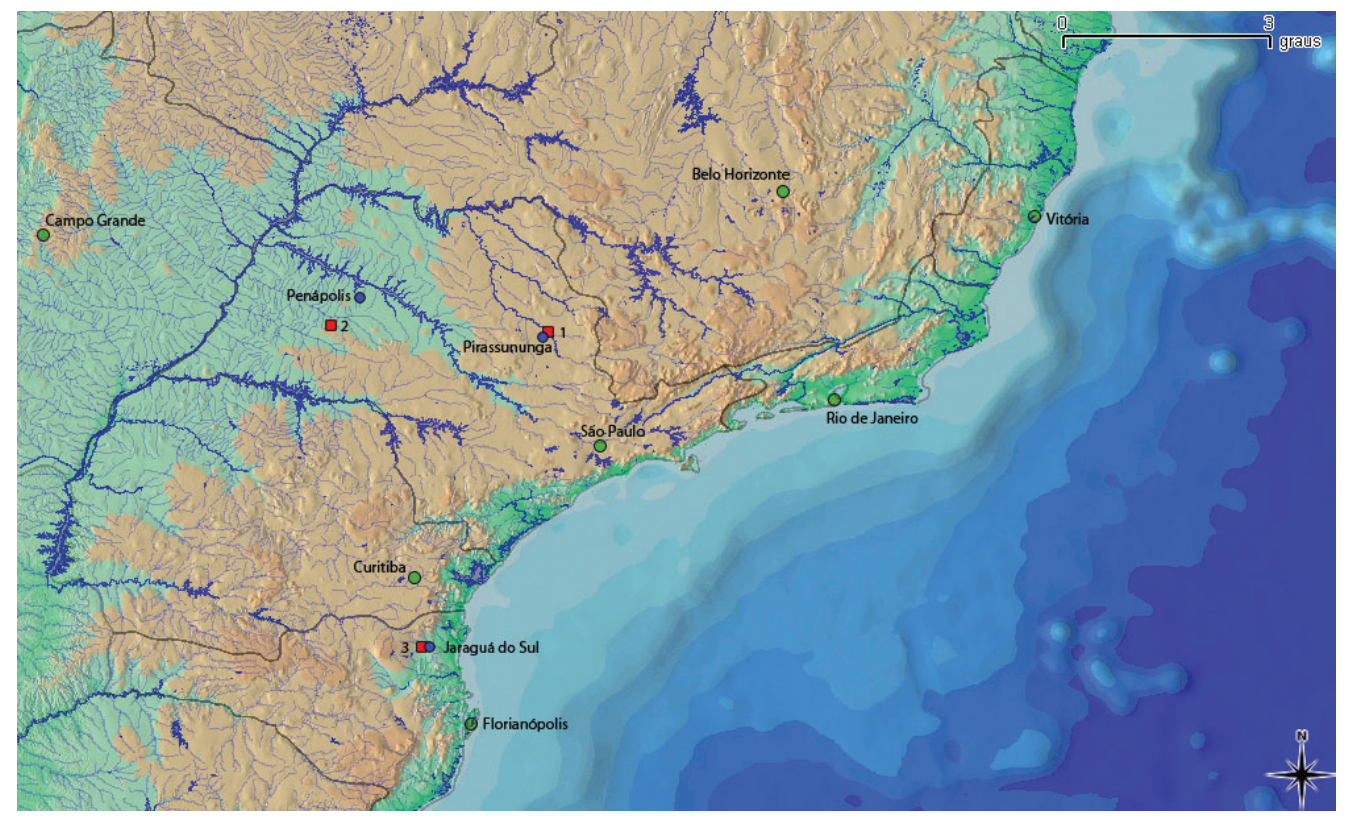

Figure 1 - Partial hydrographic map of Brazil showing the collection sites for the species of Hypostomus found in the upper Paraná River basin and Atlantic coastal rivers. The collection sites marked by red squares are: 1 - Mogi-Guaçu River (GPS: $21^{\circ} 55^{\prime} 37.6^{\prime \prime} \mathrm{S}$ and 47 $22^{\prime} 04.4^{\prime \prime} \mathrm{W}$ ), 2 - Carrapato River (GPS: $21^{\circ} 50^{\prime} \mathrm{S}$ and $50^{\circ} 30^{\prime} \mathrm{W}$ ); and 3 - Cavalo Stream (GPS: $26^{\circ} 28^{\prime} 15^{\prime \prime} \mathrm{S}$ and $49^{\circ} 10^{\prime} 57^{\prime \prime} \mathrm{W}$ ). Blue circles indicate the cities closest to the collection sites and green circles indicate the corresponding state capitals. 
Table 1 - Hypostomus species analyzed in this study. The fish were deposited in the ichthyological collection of the Laboratório de Biologia e Genética de Peixes (LBP), UNESP Botucatu, São Paulo, Brazil.

\begin{tabular}{llcc}
\hline Species & Collection site & LBP no. & Specimens analyzed \\
\hline Hypostomus aff. agna & Cavalo Stream, Jaraguá do Sul, SC (southern Brazilian coastal River basin) & 2360 & 2 males and 2 females \\
Hypostomus cf. heraldoi & Mogi-Guaçu River, Pirassununga, SP (Mogi-Guaçu River basin) & 4208 & 2 males and 2 females \\
Hypostomus regani & Mogi-Guaçu River, Pirassununga, SP (Mogi-Guaçu River basin) & 3943 & 8 males and 2 females \\
Hypostomus cf. topavae & Carrapato Stream, Penápolis, SP (Paraná River basin) & 3249 & 2 males and 2 females \\
Hypostomus sp. & Mogi-Guaçu River, Pirassununga, SP (Mogi-Guaçu River basin) & 3943 & 2 males and 2 females \\
\hline
\end{tabular}

\section{Results and Discussion}

The five species analyzed (Table 2) showed diploid numbers ranging from $2 \mathrm{n}=68$ chromosomes in Hypostomus sp. to $2 \mathrm{n}=80$ in Hypostomus cf. topavae. All of the species, except for Hypostomus regani, were analyzed karyotypically for the first time. There were no sexlinked chromosomal differences in any of the species.

Specimens of Hypostomus cf. heraldoi, from the Mogi-Guaçu River, had a diploid number of $2 \mathrm{n}=72$ chromosomes composed of $6 \mathrm{~m}, 6 \mathrm{sm}, 26 \mathrm{st}$ and 34 a (Figure 2A, Table 2). This diploid number was the same as in $H$. goyazensis (Alves et al., 2006), H. regani (Artoni and Bertollo, 1996; Alves et al., 2006) and Hypostomus sp. B, Hypostomus sp. C, Hypostomus sp. D1 and Hypostomus sp. D2 (Artoni and Bertollo, 1996) (Table 2), although all of these species can be differentiated by their karyotypic organization.

Hypostomus regani, from the Mogi-Guaçu River, had $2 \mathrm{n}=72$ chromosomes, with a karyotypic formula of $6 \mathrm{~m}$, $6 \mathrm{sm}, 32$ st and 28 a (Figure 2B, Table 2), which partially confirmed the results of Artoni and Bertollo (1996) and Alves et al. (2006), who observed the same diploid number as found here but different karyotypic formulas (Table 2). Hypstomus regani is one of the most widely-distributed species throughout the Paraná-Paraguay River basin. Based on alloenzymatic data, Zawadzki et al. (2008b) identified genetically-structured populations of $H$. regani from the Manso Reservoir (Paraguay River basin), Itaipu Reservoir (lower portion of the upper Paraná River basin) and Corumbá Reservoir (upper portion of the upper Paraná River basin). These findings indicate that differences in the karyotypic formulas of $H$. regani populations are not uncommon.

Hypostomus sp., from the Mogi-Guaçu River, had $2 \mathrm{n}=68$ chromosomes that consisted of $6 \mathrm{~m}, 6 \mathrm{sm}, 32 \mathrm{st}$ and 24 a (Figure 2C, Table 2). This diploid number was also found in $H$. ancistroides (Michele et al., 1977; Artoni and Bertollo, 1996; Alves et al., 2006). However, Hypostomus sp. differs from $H$. ancistroides in its karyotypic structure (Table 2).

Hypostomus aff. agna, from Cavalo Stream, had $2 \mathrm{n}=74$ chromosomes, with $8 \mathrm{~m}, 10 \mathrm{sm}, 32 \mathrm{st}$ and 24 a (Figure $3 \mathrm{~A}$, Table 2). This diploid number was also observed in H. paulinus, H. strigaticeps (Michele et al., 1977) and $H$. albopunctatus (Artoni and Bertollo, 1996) (Table 2), but all
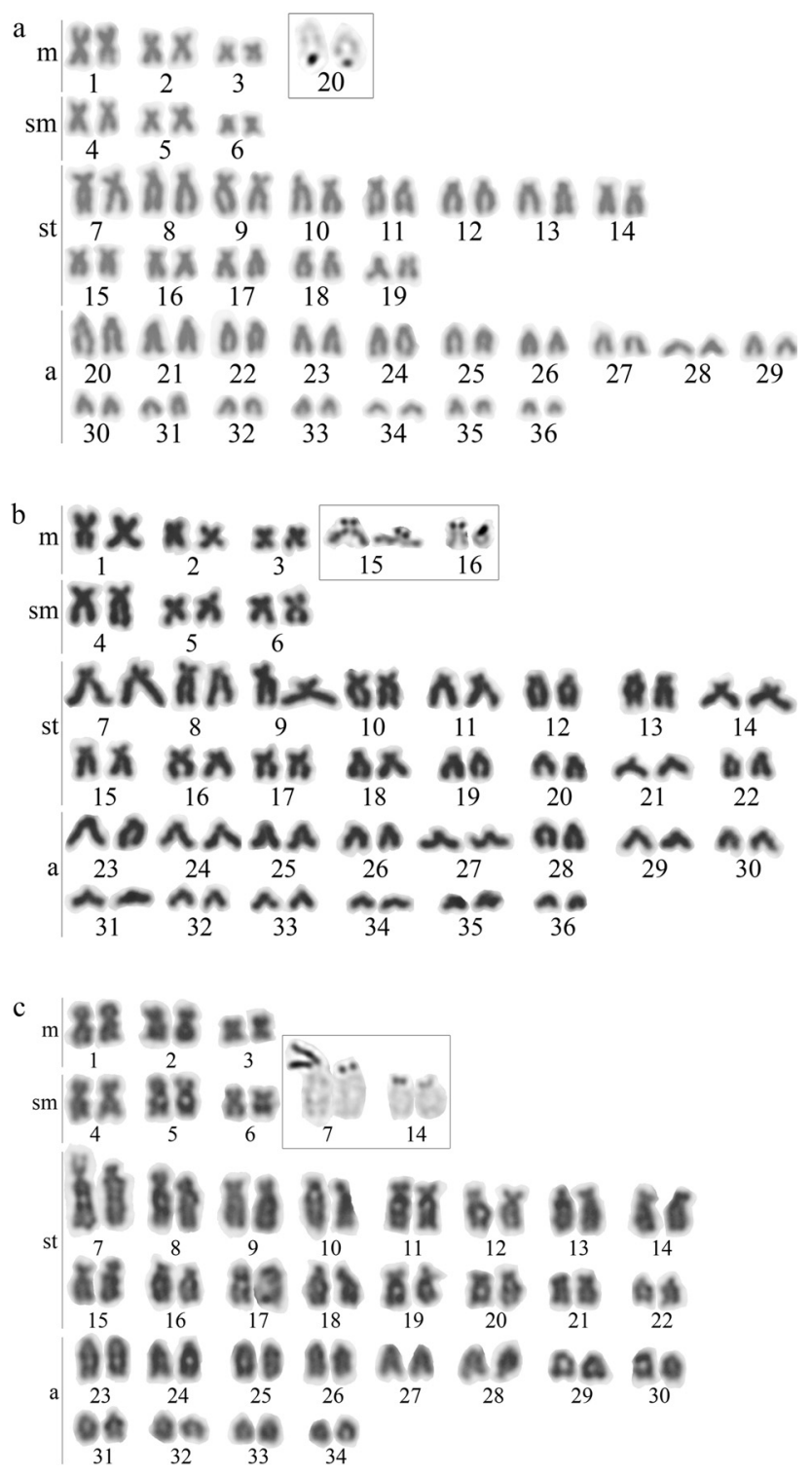

Figure 2 - Karyotypes and NOR-bearing chromosomes (insets) of: a) Hypostomus cf. heraldoi, b) Hypostomus regani and c) Hypostomus sp., all from the Mogi-Guaçu River.

of these species can also be differentiated by their karyotypic structure.

Hypostomus cf. topavae, from Carrapato Stream, had $2 \mathrm{n}=80$ chromosomes, consisting of $6 \mathrm{~m}, 8 \mathrm{sm}, 42 \mathrm{st}$ and 24 
Table 2 - Summary of the available cytogenetic data for Hypostomus.

\begin{tabular}{|c|c|c|c|c|c|}
\hline Species & Location & $2 n$ & Karyotype & NOR & Reference \\
\hline Hypostomus aff. agna & $\begin{array}{l}\text { Cavalo Stream, Jaraguá do Sul, SC (southern } \\
\text { Brazilian coastal River basin) }\end{array}$ & 74 & $8 m+10 s m+32 s t+24 a$ & 2 & This study \\
\hline Hypostomus affinis & Jacuí Stream, SP (Paraíba do Sul River basin) & 66 & $14 \mathrm{~m}+14 \mathrm{sm}+12 \mathrm{st}+26 \mathrm{a}$ & 3 & Kavalco et al. (2004) \\
\hline$H$. aff. auroguttatus & $\begin{array}{l}\text { Mogi-Guaçu River, Pirassununga, SP (Mogi- } \\
\text { Guaçu River basin) }\end{array}$ & 76 & $8 \mathrm{~m}+30 \mathrm{sm}+38 \mathrm{st} / \mathrm{a}$ & 1 & $\begin{array}{l}\text { Artoni and Bertollo } \\
\text { (1996) }\end{array}$ \\
\hline H. albopunctalus & $\begin{array}{l}\text { Mogi-Guaçu River, Pirassununga, SP (Mogi- } \\
\text { Guaçu River Basin) }\end{array}$ & 74 & $10 \mathrm{~m}+20 \mathrm{sm}+44 \mathrm{st} / \mathrm{a}$ & 3 & $\begin{array}{l}\text { Artoni and Bertollo } \\
\text { (1996) }\end{array}$ \\
\hline H. ancistroides & $\begin{array}{l}\text { Monjolinho Stream, São Carlos, SP (Piracicaba } \\
\text { River basin) }\end{array}$ & 68 & $16 \mathrm{~m}+18 \mathrm{sm}+34 \mathrm{st} / \mathrm{a}$ & 3 & $\begin{array}{l}\text { Artoni and Bertollo } \\
\text { (1996) }\end{array}$ \\
\hline H. ancistroides & - & 68 & $10 \mathrm{~m}+28 \mathrm{sm}+30 \mathrm{st} / \mathrm{a}$ & - & Michele et al. (1977) \\
\hline H. ancistroides & Araquá River, Botucatu, SP (Tietê River basin) & 68 & $18 \mathrm{~m}+10 \mathrm{sm}+12 \mathrm{st}+28 \mathrm{a}$ & 3 & Alves et al. (2006) \\
\hline H. emarginatus & $\begin{array}{l}\text { Araguaia River, Barra do Garças, MT } \\
\text { (Araguaia River basin) }\end{array}$ & 52 & $16 \mathrm{~m}+30 \mathrm{sm}+6 \mathrm{st}$ & 1 & $\begin{array}{l}\text { Artoni and Bertollo } \\
(2001)\end{array}$ \\
\hline H. goyazensis & $\begin{array}{l}\text { Vermelho River, Goiás Velho, GO (Araguaia } \\
\text { River basin) }\end{array}$ & 72 & $10 \mathrm{~m}+16 \mathrm{sm}+10 \mathrm{st}+36 \mathrm{a}$ & 1 & Alves et al. (2006) \\
\hline Hypostomus cf. heraldoi & $\begin{array}{l}\text { Mogi-Guaçu River, Pirassununga, SP } \\
\text { (Mogi-Guaçu River basin) }\end{array}$ & 72 & $6 m+6 s m+26 s t+34 a$ & 1 & This study \\
\hline H. macrops & - & 68 & $10 \mathrm{~m}+14 \mathrm{sm}+44 \mathrm{st} / \mathrm{a}$ & - & Michele et al. (1977) \\
\hline H. nigromaculatus & $\begin{array}{l}\text { Mogi-Guaçu River, Pirassununga, SP (Mogi- } \\
\text { Guaçu River basin) }\end{array}$ & 76 & $8 m+20 s m+48 s t / a$ & 1 & Rubert et al. (2008) \\
\hline H. nigromaculatus & $\begin{array}{l}\text { Três Bocas Stream, Londrina, PR (Tibagi River } \\
\text { basin) }\end{array}$ & 76 & $6 \mathrm{~m}+20 \mathrm{sm}+50 \mathrm{st} / \mathrm{a}$ & 2 & Rubert et al. (2008) \\
\hline H. nigromaculatus & $\begin{array}{l}\text { Ribeirão dos Apertados, Londrina, PR (Tibagi } \\
\text { River basin) }\end{array}$ & 76 & $8 m+20 s m+48 s t / a$ & 2 & Rubert et al. (2008) \\
\hline H. paulinus & - & 74 & $10 \mathrm{~m}+20 \mathrm{sm}+44 \mathrm{st} / \mathrm{a}$ & - & Michele et al. (1977) \\
\hline H. regani & $\begin{array}{l}\text { Mogi-Guaçu River, Pirassununga, SP (Mogi- } \\
\text { Guaçu River basin) }\end{array}$ & 72 & $6 m+6 s m+32 s t+28 a$ & 2 & This study \\
\hline H. regani & $\begin{array}{l}\text { Mogi-Guaçu River, Pirassununga, SP (Mogi- } \\
\text { Guaçu River basin) }\end{array}$ & 72 & $10 \mathrm{~m}+20 \mathrm{sm}+42 \mathrm{st} / \mathrm{a}$ & - & $\begin{array}{l}\text { Artoni and Bertollo } \\
\text { (1996) }\end{array}$ \\
\hline H. regani & Araquá River, Botucatu, SP (Tietê River basin) & 72 & $12 m+18 s m+26 s t+16 a$ & 1 & Alves et al. (2006) \\
\hline H. strigaticeps & - & 74 & $8 m+4 s m+62 s t / a$ & - & Michele et al. (1977) \\
\hline Hypostomus cf. topavae & $\begin{array}{l}\text { Carrapato Stream, Penápolis, SP (Paraná River } \\
\text { basin) }\end{array}$ & 80 & $6 m+8 s m+42 s t+24 a$ & 2 & This study \\
\hline Hypostomus sp. & $\begin{array}{l}\text { Mogi-Guaçu River, Pirassununga, SP (Mogi- } \\
\text { Guaçu River basin) }\end{array}$ & 68 & $6 m+6 s m+32 s t+24 a$ & 2 & This study \\
\hline Hypostomus sp. 2 & $\begin{array}{l}\text { Perdido River, Planalto da Bodoquena, MS } \\
\text { (Paraguai River basin) }\end{array}$ & 84 & $6 m+16 s m+62 s t / a$ & 1 & Cereali et al. (2008) \\
\hline Hypostomus sp. 3 & $\begin{array}{l}\text { Salobrinha Stream, Planalto da Bodoquena MS } \\
\text { (Paraguai River basin) }\end{array}$ & 82 & $6 m+12 s m+64 s t / a$ & 1 & Cereali et al. (2008) \\
\hline Hypostomus sp. 3 & $\begin{array}{l}\text { Salobrinha Stream, Planalto da Bodoquena, MS } \\
\text { (Paraguai River basin) }\end{array}$ & 84 & $6 m+12 s m+66 s t / a$ & 1 & Cereali et al. (2008) \\
\hline Hypostomus sp. A & $\begin{array}{l}\text { Rincão River, Rincão, SP (Piracicaba River ba- } \\
\text { sin) }\end{array}$ & 70 & $18 \mathrm{~m}+14 \mathrm{sm}+38 \mathrm{st} / \mathrm{a}$ & 2 & $\begin{array}{l}\text { Artoni and Bertollo } \\
\text { (1996) }\end{array}$ \\
\hline Hypostomus sp. B & $\begin{array}{l}\text { Mogi-Guaçu River, Pirassununga, SP (Mogi- } \\
\text { Guaçu River basin) }\end{array}$ & 72 & $12 \mathrm{~m}+18 \mathrm{sm}+42 \mathrm{st} / \mathrm{a}$ & 1 & $\begin{array}{l}\text { Artoni and Bertollo } \\
\text { (1996) }\end{array}$ \\
\hline Hypostomus sp. C & $\begin{array}{l}\text { Mogi-Guaçu River, Pirassununga, SP (Mogi- } \\
\text { Guaçu River basin) }\end{array}$ & 72 & $10 \mathrm{~m}+18 \mathrm{sm}+44 \mathrm{st} / \mathrm{a}$ & 2 & $\begin{array}{l}\text { Artoni and Bertollo } \\
\text { (1996) }\end{array}$ \\
\hline Hypostomus sp. D1 & $\begin{array}{l}\text { Mogi-Guaçu River, Pirassununga, SP (Mogi- } \\
\text { Guaçu River basin) }\end{array}$ & 72 & $10 \mathrm{~m}+26 \mathrm{sm}+36 \mathrm{st} / \mathrm{a}$ & 2 & $\begin{array}{l}\text { Artoni and Bertollo } \\
\text { (1996) }\end{array}$ \\
\hline Hypostomus sp. D2 & $\begin{array}{l}\text { Mogi-Guaçu River, Pirassununga, SP (Mogi- } \\
\text { Guaçu River basin) }\end{array}$ & 72 & $14 \mathrm{~m}+20 \mathrm{sm}+38 \mathrm{st} / \mathrm{a}$ & 2 & $\begin{array}{l}\text { Artoni and Bertollo } \\
\text { (1996) }\end{array}$ \\
\hline Hypostomus sp. E & $\begin{array}{l}\text { Mogi-Guaçu River, Pirassununga, SP (Mogi- } \\
\text { Guaçu River basin) }\end{array}$ & 80 & $8 m+16 s m+56 s t / a$ & 2 & $\begin{array}{l}\text { Artoni and Bertollo } \\
\text { (1996) }\end{array}$ \\
\hline
\end{tabular}

$2 \mathrm{n}=$ diploid number; $\mathrm{a}=$ acrocentric $; \mathrm{m}=$ metacentric; $\mathrm{sm}=$ submetacentric; $\mathrm{st}=$ subtelocentric. $\mathrm{NOR}=$ number of chromosomal pairs with nucleolar organizer regions. 
a

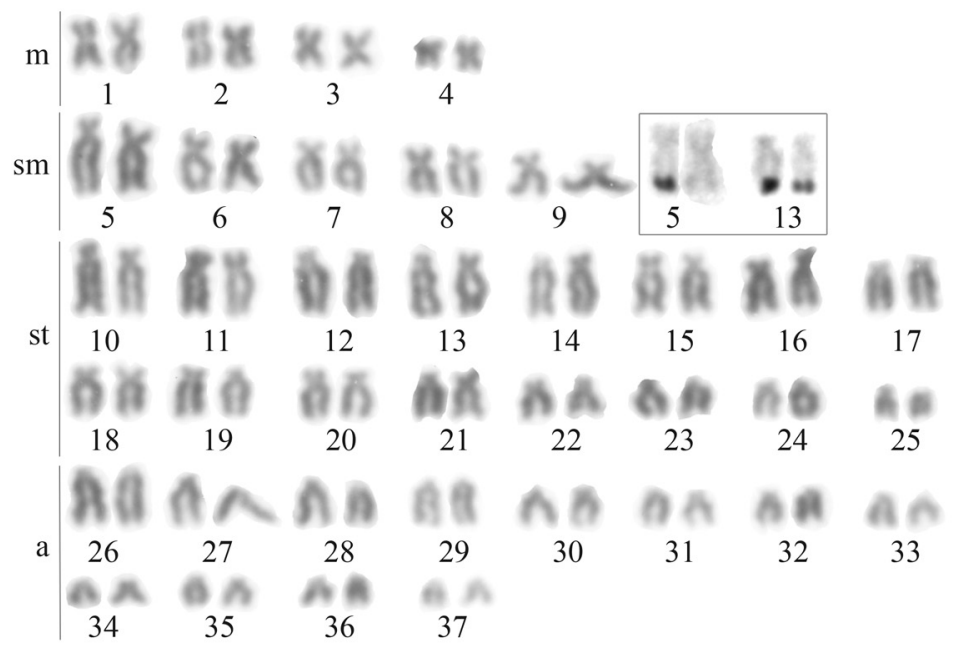

b
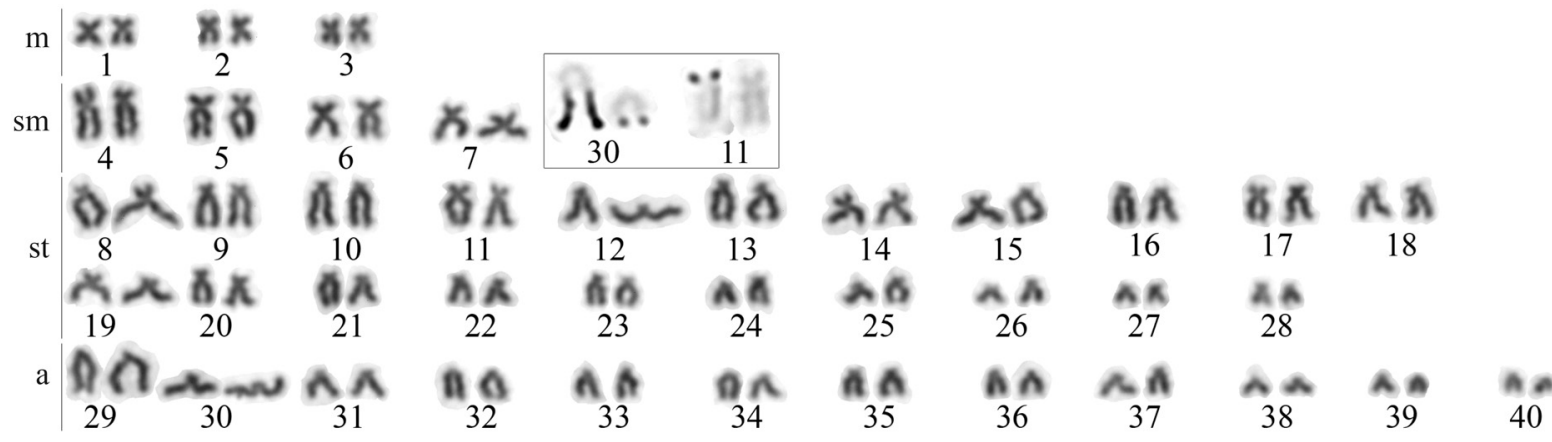

Figure 3 - Karyotypes and NOR-bearing chromosomes (insets) of: a) Hypostomus aff. agna from Cavalo Stream and b) Hypostomus cf. topavae from Carrapato Stream.

a (Figure 3B, Table 2). This diploid number was also found in Hypostomus sp. E (Artoni and Bertollo, 1996) (Table 2), although $H$. cf. topavae can be differentiated from its congeners by its karyotypic organization.

Based on cytogenetic studies, Artoni and Bertollo (2001) found that in the Hypostominae higher chromosomal numbers are associated with a greater number of uniarmed chromosomes, whereas low diploid numbers are associated with a higher number of biarmed chromosomes. Similarly, the high diploid numbers in Hypostomus are associated with a high number of uniarmed chromosomes (Table 2). Alves et al. $(2003,2005,2006)$ suggested that the diploid number $2 n=54$ and the presence of many biarmed chromosomes are primitive characteristics of the Loricariidae. Their conclusion was based mainly on the wide occurrence of this diploid number and karyotypic formulas in basal loricariid taxa, such as members of the subfamilies Neoplecostominae and Hypoptopomatinae. The available data (Table 2) therefore corroborate and reinforce the hypothesis of Artoni and Bertollo (1996) that centric fissions and pericentric inversions have had an important role in the evolution of this fish group.

Our results showed that Hypostomus species have single or multiple NORs in the terminal position of their chromosomes, as observed in other species of this genus (Table 2). In $H$. cf. heraldoi, NORs occurred on the long arm of an acrocentric chromosomal pair (pair 20) (Figure 2A, Table 2); in H. regani, NORs occurred on the short arms of two subtelocentric chromosomal pairs (pairs 15 and 16) (Figure 2B, Table 2); in Hypostomus sp., from the Mogi-Guaçu River, NORs occurred on the short arms of two subtelocentric chromosomal pairs (pairs 7 and 14) (Figure 2C, Table 2); in H. aff. agna, NORs occurred on the long arms of two chromosomal pairs, one submetacentric (pair 5) and one subtelocentric (pair 13) (Figure 3A, Table 2); finally, in $H$. cf. topavae, NORs occurred on two chromosomal pairs: on the short arms of a subtelocentric (pair 11) and on the long arms of an acrocentric pair (pair 30) (Figure 3B, Table 2). These finding highlight the extensive diversity in NOR phenotype among the Loricariidae.

Oliveira and Gosztonyi (2000) stated that in the Siluriformes the basal NOR condition was probably a single NOR at a terminal position on the chromosome. Artoni and Bertollo (1996) proposed that NORs located terminally on the long arm of a single metacentric chromosomal pair represented the primitive condition in the Hypostominae. Based on these hypotheses, species with multiple NORs 
would be derived in a monophyletic group. Since most Hypostomus species studied here had multiple NORs, we suggest that these NORs either originated independently among Hypostomus species or originated only once in a monophyletic Hypostomus group.

The hypothesis that the five Hypostomus species analyzed here represent a derived cytogenetic condition is coherent with the available biogeographic data for Hypostomus. Based on geological and molecular data, Montoya-Burgos (2003) estimated that the origin of the main clade of Hypostomus was on the former Amazon River basin. According to this author, the vicariant and dispersal events from Amazonian areas to Paraná-Paraguayan areas occurred about 10-12 million years ago. Thus, if the cytogenetic hypotheses are congruent with the biological evolution of Hypostomus, then Amazon basin species should have chromosomal numbers close to $2 \mathrm{n}=54$ and a single NOR in the terminal position. However, although Hypostomus species have been described from the Amazon River basin (Weber, 2003; Zawadzki et al., 2008a) only $H$. emarginatus has been karyotyped. If we consider that some authors consider $H$. emarginatus as pertaining to the genus Squaliforma (Weber 3003; Ferraris 2007; Eschmeyer, 2011), then, to date, no nominal Hypostomus species from the Amazon River basin have been karyotyped. Clearly, an adequate understanding of the karyotypic evolutionary history of Hypostomus requires detailed cytogenetic studies of Amazonian species.

\section{Acknowledgments}

The authors thank Cristiane K. Shimabukuro-Dias and Osvaldo T. Oyakawa for their critic analysis and suggestions on the manuscript, José A. Senhorini for help in collecting samples from the Mogi-Guaçu River, José Carlos P. Alves for help in collecting samples from Carrapato Stream and Renato Devidé for technical assistance. We also thank Centro de Pesquisa e Treinamento em Aquicultura (CEPTA) and Núcleo de Pesquisas em Limnogia, Ictiologia e Aqüicultura (Nupelia) for logistic support. This study was partially supported by grants from Fundação de Amparo à Pesquisa do Estado de São Paulo (FAPESP), Coordenadoria de Aperfeiçoamento de Pessoal de Nível Superior (CAPES) and Conselho Nacional de Desenvolvimento Científico e Tecnológico (CNPq, grant nos. $140644 / 2005-9,300314 / 2003-5$ and $306066 / 2009-2$ to E.R.M.M., C.O. and C.H.Z., respectively).

\section{References}

Alves AL, Oliveira C and Foresti F (2003) Karyotype variability in eight species of the subfamilies Loricariinae and Ancistrinae (Teleostei, Siluriformes, Loricariidae). Caryologia 56:57-63.

Alves AL, Oliveira C and Foresti F (2005) Comparative cytogenetic analysis of eleven species of subfamilies Neople- costominae and Hypostominae (Siluriformes, Loricariidae). Genetica 124:127-136.

Alves AL, Oliveira C, Nirchio M, Granado A and Foresti F (2006) Karyotypic relationships among the tribes of Hypostominae (Siluriformes, Loricariidae) with description of XO sex chromosome system in a Neotropical fish species. Genetica 128:1-9.

Armbruster JW (2004) Phylogenetic relationships of the suckermouth armored catfishes (Loricariidae) with particular emphasis on the Hypostominae and the Ancistrinae. Zool J Linn Soc 141:1-80.

Artoni RF and Bertollo LAC (1996) Cytogenetic studies on Hypostominae (Pisces, Siluriformes, Loricariidae). Considerations on karyotype evolution in the genus Hypostomus. Caryologia 49:81-90.

Artoni RF and Bertollo LAC (2001) Trends in the karyotype evolution of Loricariidae fish (Siluriformes). Hereditas 134:201-210.

Artoni RF, Venere PC and Bertollo LAC (1998) A heteromorphic ZZ/ZW sex chromosome system in fish, genus Hypostomus (Loricariidae). Cytologia 63:421-425.

Burgess WE (1989) An Atlas of Freshwater and Marine Catfishes. A Preliminary Survey of Siluriformes. T.F.H. Publications, Neptune, 784 pp.

Carvalho PH, Lima FCT and Zawadzki CH (2010) Two new species of the Hypostomus cochliodon group (Siluriformes, Loricariidae) from the rio Negro basin in Brazil. Neotrop Ichthyol 8:39-48.

Cereali SS, Pomini E, Rosa R, Zawadzki CH, Froehlich O and Giuliano-Caetano L (2008) Karyotype description of two species of Hypostomus (Siluriformes, Loricariidae) of the Planalto da Bodoquena, Brazil. Genet Mol Res 7:583-591.

Chiachio MC, Oliveira C and Montoya-Burgos JI (2008) Molecular systematic and historical biogeography of the armored Neotropical catfishes Hypoptopomatinae and Neoplecostominae (Siluriformes, Loricariidae). Mol Phylogenet Evol 49:606-617.

Ferraris CJ (2007) Checklist of catfishes, recent and fossil (Osteichthyes, Siluriformes), and catalogue of siluriform primary types. Zootaxa 1418:1-628.

Foresti F, Almeida Toledo LF and Toledo Filho SA (1981) Polymorphic nature of nucleolus organizer regions in fishes. Cytogenet Cell Genet 31:137-144.

Garavello JC and Garavello JP (2004) Spatial distribution and interaction of four species of the catfish genus Hypostomus Lacépède with bottom of Rio São Francisco, Canindé do São Francisco, Sergipe, Brazil (Pisces, Loricariidae, Hypostominae). Braz J Biol 64:591-598.

Howell WM and Black DA (1980) Controlled silver staining of nucleolus organizer regions with a protective colloidal developer: A 1-step method. Experientia 36:1014-1015.

Kavalco KF, Pazza R, Bertollo LAC and Moreira-Filho O (2004) Heterochromatin characterization of four fish species of the family Loricariidae (Siluriformes). Hereditas 141:237-242.

Levan A, Fregda K and Sandberg AA (1964) Nomenclature for centromeric position on chromosomes. Hereditas 52:201220.

Mazzoni R, Caramaschi U and Weber C (1994) Taxonomical revision of the species of Hypostomus Lacépède, 1803 (Siluriformes, Loricariidae) from lower Rio Paraíba do Sul, State of Rio de Janeiro, Brazil. Rev suis Zool 101:3-18. 
Michele JL, Takahashi CS and Ferrari I (1977) Karyotypic study of some species of the family Loricariidae (Pisces). Cytologia 42:539-546.

Montoya-Burgos JI (2003) Historical biogeography of the catfish genus Hypostomus (Siluriformes, Loricariidae), with implications on the diversification of Neotropical ichthyofauna. Mol Ecol 12:1855-1867.

Muller S and Weber C (1992) Les dents des sous-familles Hypostominae et Ancistrinae (Pisces, Loricariidae) et leur valeur taxonomique. Rev suis Zool 99:747-754.

Nelson JS (2006) Fishes of the World. 4th edition. John Wiley \& Sons, Hoboken, $601 \mathrm{pp}$.

Oliveira C and Gosztonyi AE (2000) A cytogenetic study of Diplomystes mesembrinus (Teleostei, Siluriformes, Diplomistidae) with a discussion of chromosome evolution in siluriforms. Caryologia 53:31-37.

Oyakawa OT, Akama A and Zanata AM (2005) Review of the genus Hypostomus Lacépède, 1803 from Rio Ribeira de Iguape basin, with description of a new species (Pisces, Siluriformes, Loricariidae). Zootaxa 921:1-27.

Reis RE, Kullander SO and Ferraris-Jr CJ (2003) Check List of the Freshwater Fishes of South and Central America. EDIPUCRS, Porto Alegre, 742 pp.

Reis RE, Pereira EHL and Armbruster JH (2006) Delturinae, a new loricariid catfish subfamily (Teleostei, Siluriformes), with revisions of Delturus and Hemipsilichthys. Zool J Linn Soc 147:277-299.

Reis RE, Weber C and Malabarba LR (1990) Review of the genus Hypostomus Lacépède, 1803 from Southern Brazil, with descriptions of three new species (Pisces, Siluriformes, Loricariidae). Rev suis Zool 97:729-766.

Rubert M, Zawadzki CH and Giuliano-Caetano L (2008) Cytogenetic characterization of Hypostomus nigromaculatus (Siluriformes, Loricariidae). Neotrop Ichthyol 6:93-100.

Schaefer SA (1987) Osteology of Hypostomus plecostomus (Linnaeus), with a phylogenetic analysis of the Loricariidae subfamilies (Pisces, Siluroidei). Contrib Sci 394:1-31.
Schubart O (1964) Sobre algumas Loricariidae da bacia do Rio Mogi-Guaçu. Bol Mus Nac Zool 251:1-19.

Suzuki HI, Agostinho AA and Winemiller KO (2000) Relationship between oocyte morphology and reproductive strategy in loricariid Catfishes of the Paraná River, Brazil. J Fish Biol 57:791-807.

Weber C (2003) Subfamily Hypostominae (Armored catfishes). In: Reis RE, Kullander SO and Ferraris-Jr CJ (eds) Check List of the Freshwater Fishes of South and Central America. EDIPUCRS, Porto Alegre, pp 351-372.

Weber C and Montoya-Burgos JI (2002) Hypostomus fonchii sp. n. (Siluriformes, Loricariidae) from Peru, a key species suggesting the synonymy of Cochliodon with Hypostomus. Rev suis Zool 109:355-368.

Zawadzki CH, Birindelli JLO and Lima FCT (2008a) A new pale-spotted species of Hypostomus Lacépède (Siluriformes, Loricariidae) from the rio Tocantins and rio Xingu basins in central Brazil. Neotrop Ichthyol 6:395-402.

Zawadzki CH, Renesto E, Peres MD and Paiva S (2008b) Allozyme variation among three populations of the armored catfish Hypostomus regani (Ihering, 1905) (Siluriformes, Loricariidae) from the Paraná and Paraguay river basins, Brazil. Genet Mol Biol 31:767-771.

Zawadzki CH, Weber C and Pavanelli CS (2008c) Two new species of Hypostomus Lacépède (Teleostei, Loricariidae) from the upper rio Paraná basin, Central Brazil. Neotrop Ichthyol 6:403-412.

\section{Internet Resources}

Eschmeyer WN (2011) Catalog of Fishes. Electronic version http://research.calacademy.org/ichthyology/cata$\log$ /fishcatmain.asp (January 5, 2011).

\section{Associate Editor: Yatiyo Yonenaga-Yassuda}

License information: This is an open-access article distributed under the terms of the Creative Commons Attribution License, which permits unrestricted use, distribution, and reproduction in any medium, provided the original work is properly cited. 